\title{
Recent Developments in Emergency Blood Transfusion
}

\author{
Hans-Gert Heuft ${ }^{a} \quad$ Mark H. Yazer ${ }^{b, c, d}$ \\ anstitute for Transfusion Medicine and Immunohaematology, University Hospital Magdeburg, Magdeburg, \\ Germany; ${ }^{b}$ Department of Pathology, University of Pittsburgh, Pittsburgh, PA, USA; 'Department of Pathology, \\ Tel Aviv University, Tel Aviv, Israel; 'Department of Clinical Immunology, University of Southern Denmark, \\ Odense, Denmark
}

The term "Renaissance" was created in the 19th century. It characterized the transition period between the Middle Ages and the Early Modern Age in Europe from the 14th to the early 17 th century. In this period the reintroduction of Greco-Roman writings, knowledge, and art led to seminal changes concerning human consciousness, literature, architecture, painting, and science. However, besides this specific meaning of "renaissance," there is still another more general understanding, in a sense that older, putatively outdated, ideas or practices may reoccur in their field after significant modifications. In this respect it is not the first time that a specific practice in transfusion medicine has experienced a renaissance. Granulocyte transfusion had largely disappeared from clinical use between 1985 and 1995 but was reinvestigated for clinical usefulness after the introduction of granulocyte colony-stimulating factor (G-CSF) for the mobilization of neutrophils in healthy donors $[1,2]$,and now we witness the renaissance of whole blood transfusion [3]. Similar to G-CSF-stimulated granulocyte concentrates that contained a much higher neutrophil dose than their predecessor products from hydrocortisone-stimulated donors, today's whole blood products are not comparable to their predecessors that were used in the 1970s. "Modern" whole blood preparations can be leucodepleted $[4,5]$, thereby avoiding the co-transfusion of unnecessary white blood cells. Leucodepletion provides several well-known advantages: it decreases the potential of inducing antibodies against leucocyte antigens so that the risk of transplant rejection, the risk of transfusion reactions, the risk of CMV infection, and possibly the risk of transfusion-associated immunomodulation are significantly reduced $[5,6]$. The hemostatic potential of leucodepleted whole blood may be stronger if the preparations contain platelets. Cold-preserved platelets retain hemostatic activity despite being stored beyond their natural life span [7]. The risk of inducing a clinically significant hemolytic reaction, if group 0 whole blood is transfused to a nongroup 0 patient in an emergency transfusion, is reduced by the selection of donors with low anti-A/anti-B isoagglutinin titers. It has been shown that up to four low titer group 0 whole blood transfusions (LT0WB) can be administered to non-group 0 adult patients without clinical signs of hemolysis $[8,9]$. Of note, LT0WB has left the military sphere and is now increasingly used in civilian trauma centers, even in Europe and elsewhere in the world [10-12]. The clinical use of LT0WB in specific vulnerable patient groups such as pediatric trauma resuscitation or females with postpartum hemorrhage is under investigation [11-13].

In this focus issue of Transfusion Medicine and Hemotherapy (TMH), we will draw our readers' attention to recent changes in emergency blood transfusion. The increasing use of whole blood is one "new" practice in this field. In this issue Mark Yazer [14] presents a brief but comprehensive overview on the practice of whole blood transfusion, in particular in the USA. However, perhaps even more important than the reintroduction of whole blood is the development of pre-hospital transfusion. As whole blood may contain red blood cells, plasma (together with preserved clotting factors), and platelets (with considerable hemostatic function after cold storage) combined in one bag, it is obvious that it might become a suitable blood product for pre-hospital blood transfusion. In this special issue of TMH, Dan Levin et al. [15] and Christopher Bjerkvig et al. [16] demonstrate this for Israeli military and civilian casualties as well as for Norwegian civilian patients with severe hemorrhage, respectively. However, the Nor-

\section{karger@karger.com} www.karger.com/tmh

\section{(C) 2021 The Author(s)}

Published by S. Karger AG, Basel

This is an Open Access article licensed under the Creative Common Attribution-NonCommercial-4.0 International License (CC BY-NC) (http://www.karger.com/Services/OpenAccessLicense), applicable to the online version of the article only. Usage and distribution for commercial purposes requires written permission.
Correspondence to:

Hans-Gert Heuft, hans-gert.heuft@med.ovgu.de 
wegian group report on whole blood and blood component transfusion (freeze-dried plasma and red blood cell concentrates) depending on the transfusion strategy of different Norwegian helicopter emergency medical services. Recently, pre-hospital blood transfusion has also been established in Germany. Unlike the USA, where LTOWB is increasingly accepted in the pre-hospital transfusion setting [17], German medical rescue centers exclusively use blood components for pre-hospital transfusion. Kathleen Selleng and colleagues [18] from Greifswald, Germany, describe their program, in particular their validation strategy, to implement the repeated use of red blood cell concentrates and liquid (thawed) plasma in a routine helicopter blood component transfusion regimen. An important aspect of severe, life-threatening bleedings is blood volume loss resulting in hemorrhagic shock. In the recent past a resuscitation model based on crystalloid as the main fluid replacement dominated clinical practice in the pre-hospital setting. Improved understanding of the risk of crystalloids and the need for early inclusion of blood products has resulted in newer resuscitation practices including the prehospital use of plasma. Kathleen Selleng and Andreas Greinacher [19] report their laboratory as well as clinical longterm experience with the supply of plasma that is stored in the liquid (thawed) phase at $4^{\circ} \mathrm{C}$ for the "just in time" availability of plasma for emergencies. Bryon Jackson and colleagues [20] critically review the clinical value of pre-hospital plasma transfusion. Finally, Heiko Lier and Dietmar Fries [21] give an overview on the current standard of care regarding blood product usage in case of massive transfusion needs. They present the current understanding of the usage of crystalloids, blood components, and coagulation factor therapy after the admission of the patients to hospital. We as transfusion medicine specialists are confident that a pre-hospital blood transfusion strategy including whole blood transfusion will be an important part of emergency blood transfusion standards in the (near) future.

\section{Conflict of Interest Statement}

There are no conflicts of interest to report.

\section{Funding Sources}

No funding was received to prepare this editorial.

\section{References}

1 Price TH, Bowden RA, Boeckh M, Bux J, Nelson K, Liles WC, et al. Phase I/II trial of neutrophil transfusions from donors stimulated with G-CSF and dexamethasone for treatment of patients with infections in hematopoietic stem cell transplantation. Blood. 2000; 95:3302-9.

2 Heuft HG, Goudeva L, Sel S, Blasczyk R. Equivalent mobilization and collection of granulocytes for transfusion after administration of glycosylated G-CSF $(3 \mu \mathrm{g} / \mathrm{kg})$ plus dexamethasone versus glycosylated G-CSF $(12 \mu \mathrm{g} / \mathrm{kg})$ alone. Transfusion. 2002;42(7):928-34.

3 Spinella PC, Cap AP. Whole blood: back to the future. Curr Opin Hematol. 2016;23:53642.

4 Picker SM, Stürner SS, Oustianskaja L, Gathof BS. Leucodepletion leads to component-like storage stability of whole blood - suggesting its homologous use? Vox Sang. 2004;87(3): 173-81.

5 Aboul Enein AA, Abdel Rahman HA, Abdel Maged MM, El Sissy MH. The effect of different methods of leucoreduction on plasma coagulation factors. Blood Coagul Fibrinolysis. 2017;28(2):117-20.

6 Da Ponte A, Bidoli E, Talamini R, Steffan A, Abbruzzese L, Toffola RT, et al. Pre-storage leucocyte depletion and transfusion reaction rates in cancer patients. Transfus Med. 2005; 15(1):37-43.

7 Seheult JN, Bahr MP, Spinella PC, Triulzi DJ, Yazer MH. The Dead Sea needs salt water. Massively bleeding patients need whole blood: the evolution of blood product resuscitation. Transfus Clin Biol. 2019;26:174-9.
8 Yazer MH, Freeman A, Harrold IM, Anto V, Neal MD, Triulzi DJ, et al. Injured recipients of low-titer group $\mathrm{O}$ whole blood have similar clinical outcomes compared to recipients of conventional component therapy: a singlecenter, retrospective study. Transfusion. 2021;61(6):1710-20.

9 Harrold IM, Seheult JN, Alarcon LH, Corcos A, Sperry JL, Triulzi DJ, et al. Hemolytic markers following the transfusion of uncrossmatched, cold-stored, low-titer, group $\mathrm{O}+$ whole blood in civilian trauma patients. Transfusion. 2020;60(Suppl 3):S24-30.

10 Hagen KG, Strandenes G, Kristoffersen EK, Braathen H, Sivertsen J, Bjerkvig CK, et al. A whole blood based resuscitation strategy in civilian medical services: experience from a Norwegian hospital in the period 2017-2020. Transfusion. 2021;61(Suppl 1):S22-31.

11 Lauby RS, Cuenca CM, Borgman MA, Fisher AD, Bebarta VS, Moore EE, et al. An analysis of outcomes for pediatric trauma warm fresh whole blood recipients in Iraq and Afghanistan. Transfusion. 2021;61(Suppl 1):S2-7.

12 Bahr TM, DuPont TL, Morris DS, Pierson SE, Esplin MS, Brown SM, et al. First report of using low-titer cold-stored type $\mathrm{O}$ whole blood in massive postpartum hemorrhage. Transfusion. 2019;59:3089-92.

13 Munoz JL, Kimura AM, Xenakis E, Jenkins DH, Braverman MA, Ramsey PS, et al. Whole blood transfusion reduces overall component transfusion in cases of placenta accreta spectrum: a pilot program. J Matern Fetal Neonatal Med. 2021;26:1-6. Online ahead of print.
14 Yazer MH. The evolution of blood product use in trauma resuscitation: change has come. Transfus Med Hemother. 2021;48. doi: 10.1159/000520011.

15 Levin D, Zur M, Shinar E, Tsadok M, et al. Low titer group 0 whole blood resuscitation in the pre-hospital setting in Israel - review of the first 2.5-years experience. Transfus Med Hemother. 2021;48. doi: 10.1159/000519623.

16 Bjerkvig CK, Strandenes G, Hervig T, Sunde GA, Apelseth TO. Pre-hospital whole blood transfusion programs in Norway. Transfus Med Hemother. 2021;48. doi:10.1159/ 000519676.

17 Yazer MH, Spinella PC, Anto V, Dunbar NM. Survey of group A plasma and low-titer group $\mathrm{O}$ whole blood use in trauma resuscitation at adult civilian level 1 trauma centers in the US. Transfusion. 2021;61(6):1757-63.

18 Selleng K, Bashin M, Henkel B, Jenichen G, Thies KC, Rudolph M, et al. Blood product supply for helicopter emergency medical service. Transfus Med Hemother. 2021;48. doi: 10.1159/000519825.

19 Selleng K, Greinacher A. 10 years of experience with the first thawed plasma bank in Germany. Transfus Med Hemother. 2021;48. doi: 10.1159/000519700.

20 Jackson BP, Sperry JL, Yazer MH. Prehospital plasma transfusion: what does the literature show? Transfus Med Hemother. 2021;48. doi: $10.1159 / 519627$.

21 Lier H, Fries D. Emergency blood transfusion for trauma and perioperative resuscitation. Transfus Med Hemother. 2021;48. doi: $10.1159 / 000519696$. 